\title{
PENSION DESIGN WHEN FERTILITY FLUCTUATES: THE ROLE OF CAPITAL MOBILITY AND EDUCATION FINANCING
}

\author{
JOVAN ŽAMAC \\ CESIFO WORKING PAPER NO. 1569 \\ CATEGORY 3: SOCIAL PROTECTION \\ OCTOBER 2005 \\ An electronic version of the paper may be downloaded \\ - from the SSRN website: \\ www.SSRN.com \\ - from the CESifo website: www.CESifo-group.de
}




\title{
PENSION DESIGN WHEN FERTILITY FLUCTUATES: THE ROLE OF CAPITAL MOBILITY AND EDUCATION FINANCING
}

\begin{abstract}
This study compares alternative designs of an unfunded pension system. Convex combinations between a fixed contribution rate and a fixed benefit rate are considered. The objective is to maximize the expected ex-ante welfare under stochastic fertility. The model is a three-period CGE framework where the design of the education system and effects on factor prices are accounted for. The effects on factor prices depend on the degree of capital mobility. For low degrees of capital mobility it is optimal to have a fixed benefit rate in the pension system. But for the small open economy, a fixed contribution rate is optimal if the education system has a fixed benefit rate. This design of education and pension systems assures that individuals in the small open economy are unaffected by fertility fluctuations.
\end{abstract}

JEL Code: J13, H55, H52.

Keywords: pension schemes, demography, social security, education, fertility.

\author{
Jovan Žamac \\ Department of Economics \\ Uppsala University \\ P.O. Box 513 \\ 75120 Uppsala \\ Sweden \\ jovan.zamac@nek.uu.se
}

I want to thank Yngve Andersson, Hans Fehr, Panu Poutvaara, and Andreas Wagener for helpful comments. I am further grateful to my supervisors Nils Gottfries and Thomas Lindh for indispensable guidance. 


\section{Introduction}

Unfunded pension systems are sensitive to changes in the dependency ratios. Given the ongoing shift in the demographic structure, particulary the increase in old age dependency, several countries have re-designed their pension systems. While still mainly unfunded, they now have a fixed contribution rate instead of a fixed replacement rate. Is a fixed contribution rate the preferred design when considering changes in dependency ratios?

Changes in old age dependency ratios can arise from three main sources: fertility, mortality, and migration. This paper deals solely with changes that arise from fertility fluctuations. Such changes are a major source of changing demographic structure and they affect economic conditions throughout the life-cycle. ${ }^{1}$ Initially, fertility shocks alter the young age dependency ratio and thus affect another important intergenerational transfer system, the education system. Further down the life-cycle, fertility fluctuations affect factor prices via changes in the capital labor ratio; how much factor prices change depends on the degree of capital mobility. In the final stage of the life-cycle, the old age dependency ratio shifts, which affects the pension system. Thus, it is necessary to account for the effects on the education system, and on factor prices, when trying to find the optimal pension design with respect to fertility fluctuations.

The aim of this paper is to find the unfunded pension design that yields the highest expected ex ante welfare when fertility fluctuates, while taking account of the education system and the degree of capital mobility. Welfare is measured according to a standard utilitarian welfare function. This corresponds to finding the pension scheme that the individuals would choose behind the veil of ignorance, i.e. before knowing if they will belong to a large or a small generation. Two thought experiments are conducted. First, the individuals are allowed to choose both the design of the education system and the pension system for a given degree of capital mobility. Second, they are only allowed to choose the design of the pension system for a given education system and degree of capital mobility. The pension system and the education system are restricted to be intergenerational transfer systems. These results are then compared to the market outcome without state intervention when children are capable of making contractual arrangements with the adults.

From the pension literature it is known that alternative unfunded pension schemes have very different distributional properties. ${ }^{2}$ In a unfunded system

\footnotetext{
${ }^{1}$ Among others Cutler et al. (1990) stresses the fact that fertility fluctuations are important.

${ }^{2}$ See for instance Hassler and Lindbeck (1997), Thøgersen (1998), Lindbeck (2000) and Wagener (2003).
} 
changes in the old age dependency ratio alter the contributions from the workers, the benefits to the retirees, or both. Which of these alternatives that occurs depends on how the pension system is designed. In this paper I analyze convex combinations between a pure fixed contribution rate (FC scheme) and a pure fixed benefit rate (FB scheme). ${ }^{3}$ In the pure FC scheme the workers always pay a certain fraction of their income to the system, irrespective of the dependency ratio. In a pure FB scheme retirees are guaranteed a certain fraction of current workers' income. Convex combinations between these two extremes imply that both workers and retirees are affected by changes in dependency ratios.

Like the pension system, the education system is mainly financed by intergenerational transfers and thus the same issues arise when fertility changes. A changing young age dependency ratio will alter the contributions from the workers, the education received by children, or both. Again it is natural to consider a fixed contribution rate or a fixed benefit rate as the extreme cases. Convex combinations between FC and FB for the education system determine how workers and children share the effect of varying young age dependency.

To assume that the education system is a convex combination between these two extreme types is not as restrictive as it may seem. This way of modelling does not hinge on a particular rationale for why the education system is financed via intergenerational transfers. It simply uses the budget restriction, which must be satisfied by any endogenously determined education system as well. What the analysis excludes are responses such that total spending on education falls, or that the benefit per student increases, when there are many to educate. It is hard to imagine any endogenous response that would yield such an outcome.

The main result is that the preferred pension design depends crucially on the degree of capital mobility. With no capital mobility, a pure FB pension scheme maximizes expected welfare. A FB pension scheme implies that a large generation receives the gain from the decrease in old age dependency ratio that occurs in the pension system. This is motivated since the large generation receives a lower wage due to capital dilution. Put differently, the reason why the $\mathrm{FB}$ pension scheme is preferred is that the returns on physical capital will be negatively correlated with the return on human capital.

For a fully open economy, when factor prices are unaffected by fertility changes, the optimal pension design is a FC scheme if the education system has a FB design. With this design for the education and pension systems,

\footnotetext{
${ }^{3}$ This convexity approach is similar to the one used in Wagener (2004). Note that a fixed benefit rate is not the same as a fixed replacement rate.
} 
the individuals in the small open economy are unaffected by fertility changes. Thus, although the education system and the pension system are sensitive to fertility fluctuations, if properly designed the two effects can cancel each other out.

When analyzing public transfer systems, it is important to have in mind why these systems exist and what their purpose is. One rationale for having these systems is that the immaturity of children prevents efficient arrangements between them and the adults (e.g. Becker and Murphy (1988), Rangel (2003)). Thus it is of interest to compare the allocations that occur with exogenous systems with the market outcome, that would arise if children could make efficient contracts with the adults. Such analysis is conducted in the end of the paper. ${ }^{4}$ It is shown that the payments from the workers to the retired that arise in the market outcome resemble a fixed contribution rate. That is, the workers transfer a fixed share of their income to the retired.

Previous studies that have investigated preferred pension designs can be divided into two strands. The first includes studies that focus on fertility fluctuations in a closed economy setup, e.g. Smith (1982), Blomquist and Wijkander (1994), and Bohn (2001). These studies find that a large cohort faces less favorable factor prices compared to surrounding generations. To counter the effects of changes in capital intensity the pension system should have a varying contribution rate. Second, there are studies that focus on factor price uncertainty in a small open economy setup (e.g. Thøgersen (1998) and Wagener (2003)). The conclusion from these studies is inconclusive from an $e x$ ante perspective. ${ }^{5}$

This paper differs from previous studies since it allows for varying degrees of openness and takes into account the effect on the education system. I find that previously obtained results for the closed economy hold irrespective of how the education system is designed. Moreover, the preferred ex ante pension design is identified for all degrees of openness. Optimal pension design is shown to depend crucially on the degree of capital mobility.

The remainder of this paper is organized as follows. Section 2 presents the general equilibrium model. In section 3, the model is calibrated and the steady state results are presented. Section 4 presents the results, while section 5 compares these results to the market outcome, in which the intergenerational contracts are determined endogenously. Section 6 contains some final remarks.

\footnotetext{
${ }^{4}$ The market outcome analysis is similar to the analysis in Boldrin and Montes (2005).

${ }^{5}$ From an ex post perspective, when the uncertainty has been realized, Wagener (2003) shows that the fixed replacement rate is preferred.
} 


\section{The model}

The framework consists of a three period overlapping generations model, with four main components: individuals who maximize their lifetime utility, firms which maximize their profit, an international capital market, and the intergenerational transfer systems for education and pension. There is also an standard intergenerational welfare function, similar to the one applied in Boadway et al. (1991), which will be used to evaluate optimal pension design.

\subsection{Modelling the transfers}

The OLG model consists of one period when young, one period when working, and one period when retired. The young receive contributions from the working population via the education system, and the retired receive contributions from the working population via the pension system. For the systems to be pure intergenerational transfers it is necessary that the budgets are balanced in each period. Assuming a period-by-period balanced budget for each system separately, makes it possible to state the transfers in period $t$ as: ${ }^{6}$

$$
\begin{gathered}
b_{E, t} N_{t}=d_{E, t} N_{t-1}, \\
b_{P, t} N_{t-2}=d_{P, t} N_{t-1},
\end{gathered}
$$

where $b_{E, t}$ denotes the per child benefit from the education system, $d_{E, t}$ is the contribution per worker to the education system, $b_{P, t}$ is the benefit per retired from the pension system, and $d_{P, t}$ denotes the contribution per worker to the pension system. These are indexed with subscript $t$ to denote that the transfer occurs in period $t$. The size of each generation is denoted by $N$, where the subscript $t$ indicates in which period the generation is born.

So far, the contributions and benefits were not related to the level of income in society. In a world with growing income over time it would not make sense to have fixed benefits/contributions over time. It is reasonable to relate the benefits/contributions to the income, where income refers to the mean income of the working generation.

Let $\tilde{w}_{t}$ denote the mean labor income of the workers in period $t$, and let $\tau_{E, t}$ and $\tau_{P, t}$ denote the contribution rate devoted for financing the education and the pension system, respectively. The contribution from the workers, $d_{i, t}$, where $i=E, P$, can then be stated as:

$$
d_{i, t}=\tilde{w}_{t} \tau_{i, t}
$$

\footnotetext{
${ }^{6}$ The assumption regarding two separate systems is mainly based on the fact the existing social security programs have a very weak connection with the education system, if any.
} 
The received benefits, $b_{i, t}$, can also be related to the income level of the working population according to:

$$
b_{i, t}=\tilde{w}_{t} \gamma_{i, t}
$$

where $\gamma_{i, t}$ are the benefit rates in the transfer systems. The benefit rates are the fraction of active workers income that each child/retired receives. ${ }^{7}$

The period-by-period balanced budget constraints for the two transfer systems can now be rewritten as:

$$
\begin{gathered}
\gamma_{E, t}=\tau_{E, t} / n_{t}, \\
\gamma_{P, t}=\tau_{P, t} n_{t-1},
\end{gathered}
$$

where $n_{t}$ denotes the young age dependency ratio in period $t$, i.e. $N_{t} / N_{t-1}$, and hence the old age dependency ratio, $N_{t-2} / N_{t-1}$, equals $n_{t-1}^{-1}$. Changes in dependency ratios must affect either the contribution rate or the benefit rate, or both.

Various intergenerational transfer schemes differ in how the benefits and the contributions respond to changes in dependency ratios. The difference between the schemes can be understood from the balanced budget restrictions. From equations (5) and (6) two simple schemes emerge. Either the benefit rate is fixed, $\gamma_{i, t}=\gamma_{i}$, or the contribution rate is fixed, $\tau_{i, t}=\tau_{i}$. These schemes will simply be referred to as fixed benefit rate, $F B$, and fixed contribution rate, FC. These are the two extreme cases. To allow for convex combinations between the extreme cases, the same approach as in Wagener (2004) will be used. ${ }^{8}$ The benefit formula for the education and the pension system are stated as:

$$
\begin{gathered}
b_{E, t}=\tilde{w}_{t} \gamma_{E}\left(\phi_{E}+\left(1-\phi_{E}\right) n / n_{t}\right), \\
b_{P, t}=\tilde{w}_{t} \gamma_{P}\left(\phi_{P}+\left(1-\phi_{P}\right) n_{t-1} / n\right),
\end{gathered}
$$

where $n$ is the steady state population growth and $\phi_{i} \in(0,1)$ indicates under which scheme the systems operate. The extreme cases are $\phi_{i}=0$,

\footnotetext{
${ }^{7}$ The term benefit rate is not to be confused with the term replacement rate. The benefit rate is a theoretical abstraction and is also used in Lindbeck (2000), though not using the same term. In the pension literature it sometimes occurs that the replacement rate refers to the fraction of current income (what is referred to as the benefit rate in this paper). This is, however, conceptually obscure since the benefits of the present pensioners does not replace the wages of present workers. Augustinovics (1999), among others, has also pointed at this misuse $\mathrm{i}$ the literature.

${ }^{8}$ There are some differences compared to Wagener (2004). Since the PAYG pension is a political process in his modell, it means that the pension system is not a priori fixed. Also he models the convex combination between the FC scheme and the FR scheme
} 
which corresponds to a pure FC scheme, and $\phi_{i}=1$, which corresponds to a pure FB scheme. In the latter case $\gamma_{i}$ is simply the fixed benefit rate. When $\phi_{i}=0, \gamma_{E} n$ represents the fixed contribution rate in the education system, and $\gamma_{E} / n$ becomes the fixed contribution rate in the pension system. The intermediate cases when $\phi_{i} \in[0,1]$ are convex combinations between the extreme cases. The parameter $\phi_{i}$ determines to which extent changes to dependency ratios affect the contributors versus beneficiaries.

The extreme points are quite natural for the education system, but for the pension system a note is warranted. Usually the fixed replacement rate, $F R$ scheme is considered as the opposite of the FC scheme. In this case the benefits received in the pension system are related to previous income instead of current income, i.e. the income from one's own active life. The main reason for why the FR scheme is excluded is because this scheme removes all incentives for the workers to invest in human capital of coming generations. This scheme could never mimic the market outcome. ${ }^{9}$

\subsection{Individuals}

Individuals live for three periods. During young age, children invest all their time (one unit) in human capital accumulation, from which they all receive the same utility. Children's time input is combined with education benefits, provided by the workers, to develop their human capital which will be used when working. Any difference in the per child education benefit will thus not affect the utility in the first period of life, but will instead alter the human capital. In the next period, when working, all supply inelastically their effective labor, the product of their one unit of time and their human capital and receive wage income. A fraction of this wage income finances the education and pension systems; the remaining part will be divided between savings and consumption. In the third and final period, individuals are retired and consume their own savings and income from the pension system.

Since all generations gain the same utility when young this period is suppressed. The lifetime utility of an individual, belonging to generation $t-1$, is assumed to be additively separable according to:

$$
U_{t-1}=\ln c_{w, t}+\beta \ln c_{r, t+1},
$$

where $\beta$ is the subjective discount factor and thus a measure of the individual's impatience to consume. Consumption per worker in period $t$ is denoted $c_{w, t}$, while consumption per retired in period $t$ is denoted $c_{r, t}$.

\footnotetext{
${ }^{9}$ It can be noted that there are only slight differences in results between the FR scheme and the FB scheme, while the former is somewhat more complicated to analyze.
} 
Denote by $h_{t}$ the human capital of generation $t-1$. This is a product of the benefits from the education system in period $t-1$, i.e.:

$$
h_{t}=b_{E, t-1}^{\sigma}
$$

where $\sigma \in(0,1]$ measures the elasticity of scale in the production of human capital. The human capital determines the effective labor supply for each individual in period $t$. The individuals take their human capital, wages, the interest rate, the tax rate, and the benefits in the pension system, as given. Their only decision variable is savings, which they choose so as to maximize lifetime utility, according to equation (9), subject to the following budget constraints:

$$
\begin{gathered}
c_{w, t}=\left(1-\tau_{t}\right) w_{t} h_{t}-s_{t}, \\
c_{r, t+1}=R_{t+1} s_{t}+b_{P, t+1} .
\end{gathered}
$$

$s_{t}$ denotes the per worker savings in period $t, w_{t}$ is the wage for one unit of effective labor, and $R_{t+1}$ denotes the gross interest rate on savings between period $t$ and $t+1$. Further, $\tau_{t}$ denotes the total tax rate used in the financing of the education and the pension systems, that is $\tau_{t}=\tau_{P, t}+\tau_{E, t}$.

The individuals use their savings either for investments in domestic firms or to lend to the rest of the world (or borrow). So we have:

$$
s_{t}=i_{t}+a_{t}
$$

where $i_{t}$ is the investments made in domestic firms, and $a_{t}$ is the amount lent out to the rest of the world, which may be negative.

Maximizing the objective function (9) under the constraints (11) and (12) yields the familiar intertemporal Euler equation:

$$
c_{r, t+1}=\beta R_{t+1} c_{w, t} .
$$

\subsection{Production}

The aggregate production function in the economy is assumed to be of CobbDouglas type and homogeneous of degree 1. Production is $Y_{t}=A K_{t}^{\alpha} L_{t}^{1-\alpha}$, where $L_{t}$ is aggregate effective labor, i.e. $L_{t}=h_{t} N_{t-1}, K_{t}$ is the aggregate capital stock in the beginning of period $t$, and $A$ is a scaling parameter. The capital stock $K_{t}$ depreciates fully during the production process. Defining production in terms of output per worker yields:

$$
y_{t}=A k_{t}^{\alpha} h_{t}^{1-\alpha}
$$

where $y_{t}=Y_{t} / N_{t-1}$, and $k_{t}=K_{t} / N_{t-1}$. 
The prices of factor inputs are obtained from the firms' maximization problem, and since perfectly competitive factor markets are assumed prices of factors equal their marginal products, that is:

$$
\begin{gathered}
R_{t}=A \alpha k_{t}^{\alpha-1} h_{t}^{1-\alpha}, \\
w_{t}=A(1-\alpha) k_{t}^{\alpha} h_{t}^{-\alpha},
\end{gathered}
$$

where $R_{t}$ is the price on physical capital, and $w_{t}$ is the price per unit of human capital, both in period $t$.

\subsection{Capital mobility}

Capital mobility determines the effect that demographic changes has on factor prices. The extreme cases are zero capital mobility, i.e. $a \equiv 0$, and full capital mobility such that $a$ can fluctuate freely so as to keep the rate of return on capital constant. These cases correspond to the the closed economy and the small perfectly open economy, respectively. By allowing for imperfect capital mobility it is possible to analyze the intermediate cases between a small perfectly open economy and the closed economy. This is of interest since not many economies are considered to be closed and there is ample evidence that the financial integration is imperfect (e.g. Obstfeld and Rogoff (2000)).

There are many possible ways to model imperfect capital mobility, or more correctly why capital flows will be less than required to keep the interest rate constant. In this paper limited capital mobility will be modelled in terms of risk-premium, similar to the specification used in Schmitt-Grohé and Uribe (2003). The interest rate is given by:

$$
R_{t}=R^{w}-\rho \frac{\left(1-\phi_{K}\right)}{\phi_{K}} a_{t-1}
$$

where $R^{w}$ is the constant world interest rate, $\rho>0$ is a scale parameter, and $\phi_{K} \in(0,1)$ is a measure of capital mobility, or degree of openness. When $\phi_{K}=1$ then there is no risk-premium and $a$ can vary freely so as to keep the marginal return on investment constant, and equal with the world interest rate, $R^{w}$. If $\phi_{K}=0$ then the risk-premium will be infinite which will lead to zero capital mobility, i.e. $a=0$.

Other specifications would yield similar results. ${ }^{10}$ In essence there will be a cost associated when trying to deviate from the autarky interest rate, how large this cost is depends on $\phi_{K}$.

\footnotetext{
${ }^{10}$ Trade costs as in Obstfeld and Rogoff (2000) would require a more elaborated model, while the outcome for factor prices would be similar.
} 


\subsection{Equilibrium}

Given the initial capital stock, $k_{0}>0$, the initial human capital stock, $h_{0}>0$, and population growth, $\left\{n_{t}\right\}_{t=0}^{\infty}$, a competitive equilibrium for this economy is a sequence of: prices $\left\{w_{t}, R_{t}\right\}_{t=0}^{\infty}$, allocations $\left\{c_{w, t}, c_{r, t}, i_{t}, a_{t}\right\}_{t=0}^{\infty}$, human and physical capital stocks $\left\{k_{t}, h_{t}\right\}_{t=0}^{\infty}$, and benefit rates and tax rates $\left\{\gamma_{E, t}, \gamma_{P, t}, \tau_{E, t}, \tau_{P, t}\right\}_{t=0}^{\infty}$, such that the individuals maximize their utility, firms maximize their profits, the budgets of the transfer systems are balanced, and that markets clear. The market clearing condition can be reduced to:

$$
k_{t+1}=i_{t} / n_{t},
$$

and $i_{t}$ has to be such that equation (13) holds.

The saving decisions characterize the equilibrium, since they define the equilibrium trajectory for $\left\{k_{t}\right\}_{t=0}^{\infty}$ via eq. (19) and (13). Eqs. (11)-(14) and (16)-(19) yield the following saving function in equilibrium:

$$
s_{t}=\frac{\beta \alpha\left(1-\tau_{t}\right) w_{t} h_{t}}{\lambda_{t}}+\frac{(1-\alpha) \gamma_{P, t+1}}{\lambda_{t} n_{t}} a_{t}
$$

where $\lambda_{t}=\alpha(1+\beta)+(1-\alpha) \gamma_{P, t+1} / n_{t}$. The savings are divided between investments, $i_{t}$, and capital transactions with rest of the world, $a_{t}$, in such a way as to equalize the marginal return on investments with the interest rate; that is, so that both equation (16) and equation (18) hold.

\subsection{The intergenerational welfare function}

To obtain a compact measure of how all generations are affected by a fertility shock, welfare is defined as:

$$
W=E\left[\sum_{t=1}^{\infty} \psi_{t} U_{t}\right]
$$

This is a pure utilitarian welfare function, implying neutrality towards the inequality in the distribution of utility. ${ }^{11}$

There are different views on how the per capita lifetime utility of generation $t$ should be weighted. The question is if the utility should be weighted by the generation size, and whether the utility of future generations should be discounted. It seems more or less necessary to account for the generation size, otherwise there would be an unequal treatment of individuals belonging

\footnotetext{
${ }^{11}$ Choosing a general utilitarian welfare function with aversion towards inequality between generations utility would strengthen the results obtained later in the paper.
} 
to generations of different size. A social discount rate will be included and the weighting factor will be the following:

$$
\psi_{t} / \psi_{t-1}=\beta_{s} n_{t}
$$

where $\beta_{s}$ is the social discount rate. In the simulation the social discount rate will be set equal to the individuals discount factor, i.e. $\beta_{s}=\beta$. The formulation allows for varying the social discounting as long as $\beta_{s} \in(0,1 / n]$. If there is population growth then the discount rate should not exceed the inverse of the population growth; if it does, then the future generations would get an ever increasing impact on the welfare function, due to their larger number. ${ }^{12}$

\section{Simulation and calibration}

\subsection{Fertility rate}

What is considered is a one period shock to the fertility rate. It is, however, uncertain if the shock will be positive or negative. This is an ex ante analysis similar to the one applied in Ball and Mankiw (2001).

The fertility rate can be stated as $n_{t+j}=n \forall j \neq 0$ and $n_{t}=n(1+x)$, where $x$ is either a positive or negative disturbance. The steady state gross population growth, $n$, will be set to 1.3 , based on the annual average for the U.S. between 1910-2001. ${ }^{13}$ Note that the each period corresponds to about 27 years. The size of the disturbance does not matter and it will be set to 20 percent, i.e. $x=\{-0.2,0.2\} .{ }^{14}$ Changes in these numbers do not alter the qualitative results.

The demographic structure used in the simulation can be stated as $n_{t+j}=$ $1.3 \forall j \neq 0$ and $n_{t}=\{1.04,1.56\}$.

\section{$3.2 \quad$ Preferences}

Regarding preferences, $\beta$ is the standard measure of the individual's impatience to consume. Using the one year estimate from Auerbach and Kotlikoff (1987) of 0.98 translates to $\beta=0.6$, since every period represents about 27 years.

\footnotetext{
${ }^{12}$ See for instance Blanchet and Kessler (1991) and Boadway et al. (1991) for a short comment concerning the weighting problem.

${ }^{13}$ The annual average, from National Vital Statistics Reports 51, no. 2, is approximately 1.01. This implies that per period $n=1.01^{27}$, since one period corresponds to 27 years.

${ }^{14}$ The size of the shock is well within reason if one considers the U.S. experiance.
} 


\subsection{Production}

There are two parameters in the production function that need to be calibrated, $\alpha$ and $A$. The share of capital income in the national product, $\alpha$, is set to one third. The scale parameter $A$ can be chosen freely since it will not alter the relative outcome in any significant way. To make the results between this study and Žamac (2005) comparable, $A$ will be set to 21.6. ${ }^{15}$

The world interest rate is assumed to be equal to the steady state interest rate in autarky, implying that $a=0$, in steady state. The parameter $\rho$ in equation (18) is chosen such that when $\phi_{K}=0.5$ and a disturbance occurs, then the interest rate will deviate half the distance towards the autarky interest rate. The debt will deviate half the distance towards the fully open economy value after a disturbance when $\phi_{K}=0.5$.

\subsection{The benefits rate and human capital}

Choosing the size of the education system and the pension system amounts to calibrating the benefit rates in steady state, $\gamma_{E}$, and $\gamma_{P}$. These are set so that the rate of return on human capital equals the rate of return on physical capital in steady state. The benefit rates will thus be set to reproduce the market outcome in steady state.

The rate of return on human capital, is determined by $\sigma$. This implies that the efficient levels for $\gamma_{E}$ and $\gamma_{P}$ are functions of $\sigma$ (and other parameters already calibrated). Since $\sigma$ is an exogenous parameter ideally one would calibrate it and then infer the optimal values for $\gamma_{E}$ and $\gamma_{P}$. Unfortunately it is very hard to get an accurate measure for $\sigma$. Card and Krueger (1992) investigate how the pupil teacher ratio affects future productivity. Translating their results, via assumptions on how the spending per pupil is related to the pupil teacher ratio, would yield $\sigma=0.165$.

Since it is hard to obtain a measure for $\sigma$ an alternative is to choose one of the benefit rates from data, and then infer the $\sigma$ that would equalize the return on human capital with the return on physical capital. It is possible to use the existing pension systems as a guideline. According to the U.S. Social Security Office of the Chief Actuary the current benefit ratio, i.e. benefit to the average wage ratio in the same period, is 0.42 . In reality, however, the ratio between working years and years of retirement is almost 2 , while in this three period model it is 1 . This would lead to a benefit rate in the pension system such that $\gamma_{P}=0.21$.

\footnotetext{
${ }^{15}$ This value was chosen in Žamac (2005) to fit the empirical growth rate of U.S., here this is not an issue since only the stationary case is considered.
} 
This value for $\gamma_{P}$ would require that $\sigma=0.16$ and $\gamma_{E}=0.06$, to equalize the return on the two forms of capital. We see that $\sigma$ is quite close to the translated estimate from Card and Krueger (1992). What can be said about the benefit rate in the education system? For the U.S. the GDP share for primary and secondary school spending has been approximately 4 percent during the last three decades and the GDP share for higher education is close to 3 percent. ${ }^{16}$ The total share of GDP spent on education thus amounts to 7 percent. Note that a $\gamma_{E}=0.06$ corresponds to $\tau_{E}=0.08$ which is not that far from the reported estimates.

Table 1: Calibrated values for the exogenous parameters.

\begin{tabular}{lcr}
\hline \hline Parameter & & Value \\
\hline Time preference & $\beta$ & 0.6 \\
Share of capital income & $\alpha$ & $1 / 3$ \\
Efficiency in human capital production & $\sigma$ & 0.16 \\
Steady state benefit rate in the pension system & $\gamma_{P}$ & 0.21 \\
Steady state benefit rate in the education system & $\gamma_{E}$ & 0.06 \\
Population gross growth rate & $n$ & 1.3 \\
Fertility shock & $x$ & \pm 0.2 \\
Total factor productivity & $A$ & 21.6 \\
Constant risk-premium parameter & $\rho$ & 0.25 \\
\hline \hline
\end{tabular}

\subsection{Steady state}

Before the model is used to study the effects of fertility changes, it is useful to report the steady state values for some key variables, according to the calibration in table 1 . The magnitude of the interest rate is quite realistic

Table 2: Steady state values according to calibration in table 1.

\begin{tabular}{llr}
\hline \hline Gross interest rate for capital & $R$ & 2.74 \\
Saving rate & $S / Y$ & $3.7 \%$ \\
Capital output ratio & $k / y$ & 0.12 \\
\hline \hline
\end{tabular}

when adjusting for the time length in the model. ${ }^{17}$ The saving ratio in

\footnotetext{
${ }^{16}$ See Rangazas (2002) p. 947.

${ }^{17}$ The reported interest rate is the compounded interest rate over 27 years, which on annual basis becomes $3.8 \%$.
} 
life-cycle models with no bequests has notorious difficulties to fit empirical facts. ${ }^{18}$ As for other similar models the saving rate is considerably below the comparable U.S. rate, which is around 6.7 percent. This should not cause large problems as long as the capital output ratio is within reasonable range. From table 2 the capital output ratio is 0.12 , i.e. 3.2 times yearly GDP, which is not far from the comparable U.S. ratio.

\section{Results}

\subsection{Choosing $\phi_{P}$ and $\phi_{E}$}

We now let the generations decide behind the veil of ignorance which education design and which pension design they will choose for a given degree of openness. Figure 1 presents this choice, i.e. the $\phi_{E}$ and $\phi_{P}$ combination that yields the highest expected welfare for different degrees of openness, $\phi_{K}$. In the simulation the space $[0,1]$ was evaluated at 51 points, with equal interval of 0.02. This was done for all $\phi_{j}$ where $j=P, E, K$.

Figure 1: Optimal pension and education combination at different degrees of capital mobility.

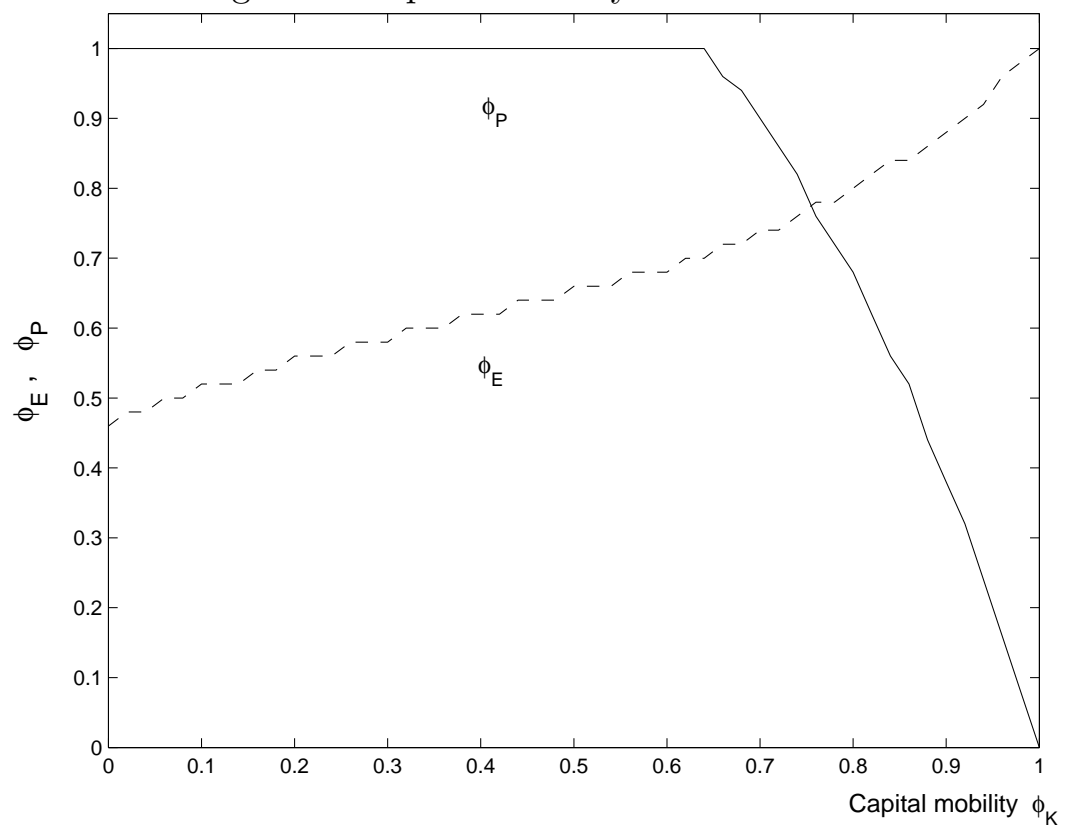

It is clear that the pure FB pension scheme, $\phi_{P}=1$, is the preferred

\footnotetext{
${ }^{18}$ See Kotlikoff and Summers (1981).
} 
design except for high degrees of capital mobility. We also see that the pure FC pension scheme, $\phi_{P}=0$, is optimal in the small open economy.

The intuition behind the results can be understood as follows. Consider a baby boom shock in one period only, i.e. $n_{t+j}=n \forall j \neq 0$ and $n_{t}>n$. This will imply a burden in the education system, and who bears this burden will be a distributional matter between the baby boom generation (the generation born in period $t$ ) and their parent generation (the generation born in period $t-1)$. How the burden is divided between these generations is determined by the scheme. If pure FB education design then the parents bear the whole burden, and if pure FC education design the children bear the burden.

The effects in the pension system are similar but of opposite sign, instead of a burden the baby boom creates a gain. This since there will be many workers compared to the retirees in period $t+1$, i.e. a temporary decrease in the old age dependency. The allocation of this gain is determined by the scheme, and it will also be a distributional matter between the baby boom generation and the parent generation. If pure FB pension design then the boom generation receives the gain, and if pure $\mathrm{FC}$ the parent generation receives the gain. The effects in the education system and the pension system are present irrespective of the degree of openness.

Consider first a fully closed economy, i.e. $\phi_{K}=0$. In this case, fertility changes affect factor prices, besides the effects on the education system and pension system. When the baby boom generation reaches productive age there will be capital dilution. This since the savings by the parent generation are not sufficient to equip the baby boom generation with the same capital per worker as before. The capital dilution burdens the baby boom through lower wage while the parent generation receives a higher interest rate on their savings. For this reason it is desirable to let the baby boom generation acquire the pension gain instead of the parent generation.

Consider now the other extreme for degree of openness, the fully open economy, $\phi_{K}=1$, no effects on factor prices. The fertility will in this case only effect the education system and the pension system, as described above. There are two effects of opposite sign which both are a distributional matter between same two generations. If the education system and the pension system are of opposite type then the same generation will receive both the burden and the gain. Otherwise, one generation will obtain the gain while the other will obtain the burden. For this reason, the optimal systems strive to be of opposite type in the small open economy.

Why is the education system FB and the pension system FC in the small open economy, and not vice versa? This question can be answered by investigating the implicit rate of return over both systems. Lets define this rate 
according to:

$$
R_{t+1}^{H}=b_{P, t+1} / d_{E, t} .
$$

Viewing education contributions as human capital investment and the pension benefits as repayments for this investment makes $R_{t+1}^{H}$ the implicit gross return on human capital investments. For the small open economy the only price that can vary is, $R_{t+1}^{H}$, since $R$ and $w$ are fixed. Table 3 shows how $R_{t+1}^{H}$ deviates after a fertility shock under the different extreme cases in the open economy. We see that when the factor price effect diminishes the systems

Table 3: $R_{t+1}^{H} / R$ for the extreme cases in a fully open economy.

\begin{tabular}{ccc}
\hline \hline Pension & \multicolumn{2}{c}{ Education } \\
& $\phi_{E}=1$ & $\phi_{E}=0$ \\
\hline$\phi_{P}=1$ & $n / n_{t}$ & $\left(n / n_{t}\right)^{\sigma}$ \\
$\phi_{P}=0$ & 1 & $\left(n_{t} / n\right)^{(1-\sigma)}$ \\
\hline \hline
\end{tabular}

strive towards the specific combination $\phi_{E}=1$ and $\phi_{P}=0$ since this keeps $R_{t+1}^{H}$ constant. With this specific combination the individuals in the small open economy are unaffected by fertility fluctuations.

Note that the pension system and the education system when viewed separately are sensitive to fertility fluctuations. The design will determine which generation that will be affected, but it will not be possible to avoid the effect. When viewed together, however, the effects cancel out for the right design combination.

\subsection{Choosing $\phi_{P}$ only}

Here the choice over $\phi_{E}$ is not available, and what has to be decided upon is $\phi_{P}$ that maximizes the objective function, for each combination of $\phi_{E}$ and $\phi_{K}$. This is a more general evaluation of the preferred pension design since it covers all possible designs of the education system. The results are presented in figure 2.

Previous studies have showed that the factor price effect dominates the gain in the pension system (e.g. Blomquist and Wijkander (1994); Bohn (2001)) in the closed economy. That is, the pension gain can only alleviate some of the burden from the factor price effect that the baby boom generation suffers from. Now we see that this result holds even for considerable degree of capital mobility. We see that even half the response in factor prices, compared to the closed economy response, is enough to motivate a pure FB 
Figure 2: Optimal pension combination for different education combinations and degrees of capital mobility.

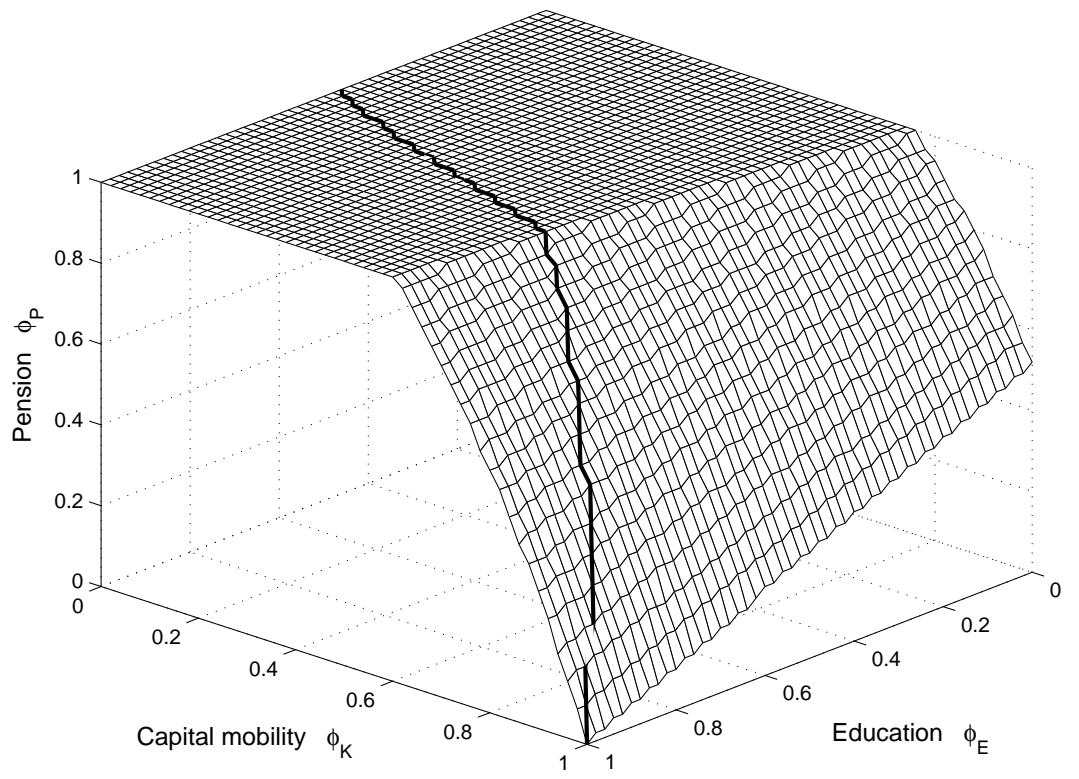

Note: The black line indicates the $\phi_{P}$ and $\phi_{E}$ pair that yields the highest expected welfare, at each degree of capital mobility, $\phi_{K}$. This was also presented in figure 1 .

pension scheme irrespective of the education scheme. This indicates that the factor price effect is strong compared to the education effect.

What emerges is that the pure FB pension scheme (i.e. $\phi_{P}=1$ ), is preferred in most cases. The opposite, i.e. the pure FC pension scheme $\left(\phi_{P}=0\right)$, is only preferred in a fully open economy, $\phi_{K}=1$, when the education system operates under a pure FB scheme, $\phi_{E}=1$.

\section{The market outcome}

An important motivation for state intervention is to correct for children's inability to enter into agreements with the adults (e.g. Becker and Murphy (1988), Rangel (2003), and Boldrin and Montes (2005)). One aim of public transfers would then be to mimic the market outcome that would occur if children where capable and allowed to make contractual agreements. This section investigates what transactions that would arise in the market outcome and compares these allocations with the transfers in the exogenous systems as analyzed previously.

The children want to finance their human capital accumulation by borrowing from the workers. While the workers want to set aside assets for 
future consumption in a way that yields the highest return. The workers would now decide how much to invest in each asset, i.e. human capital and physical capital. Their maximization problem can now be stated as:

$$
\max _{s_{t}, d_{E, t}} U=\ln c_{w, t}+\beta \ln c_{r, t+1},
$$

subject to the following budget constraints:

$$
\begin{aligned}
c_{w, t} & =w_{t} h_{t}-s_{t}-d_{E, t}-R_{t}^{H} b_{E, t-1}, \\
c_{r, t+1} & =R_{t+1} s_{t}+R_{t+1}^{H} d_{E, t},
\end{aligned}
$$

which leads to the following first order conditions:

$$
\begin{aligned}
& c_{r, t+1}=\beta R_{t+1} c_{w, t}, \\
& c_{r, t+1}=\beta R_{t+1}^{H} c_{w, t} .
\end{aligned}
$$

From above we see that they will invest in the two assets in such a way as to equalize their return, i.e. $R_{t+1}=R_{t+1}^{H}$. The efficient level of human capital investment would equalize the rate of return on savings with the marginal rate of human capital.

The children (who have no opportunity cost of education, and who receive the same utility irrespective of the quality of their education) are interested in maximizing their future income. They want to maximize:

$$
\max _{b_{E, t}} \pi=w_{t+1} h_{t+1}-R_{t+1}^{H} b_{E, t}
$$

and their first order condition is:

$$
R_{t+1}^{H}=\frac{\sigma \tilde{w}_{t+1}}{b_{E, t}} .
$$

Could this market outcome be replicated by exogenous systems? To be able to answer this question analytically only the extreme cases for capital mobility are considered. The aim is to find the corresponding benefit rates in the market outcome, for the closed economy and the small open economy. ${ }^{19}$

\subsection{Rates in the "pension system"}

Using equation (30) together with equation (23), and noting that the budget balanced restriction in equation (1) now states a market clearing condition,

\footnotetext{
${ }^{19}$ Note that the benefit rates (and the contribution rates) are always possible to define since these are just fractions of workers income.
} 
we get:

$$
\begin{aligned}
& \gamma_{P, t+1}=\sigma n_{t} \\
& \tau_{P, t+1}=\sigma=\tau_{P} .
\end{aligned}
$$

To replicate the market outcome the pension system should operate under a pure FC pension scheme, i.e. $\phi_{P}=0$. This holds irrespective of the degree of openness.

\subsection{Rates in the "education system"}

\subsubsection{Closed economy}

Solving for the workers maximization problem and using the demand condition for human capital according to equation (30), makes it possible to find the respective investment level in physical and human capital, according to:

$$
s_{t}=\frac{\beta \alpha(1-\sigma) \tilde{w}_{t}}{(1+\beta)(\alpha+\sigma(1-\alpha))},
$$

and

$$
d_{E, t}=\frac{\sigma(1-\alpha) \beta(1-\sigma) \tilde{w}_{t}}{(1+\beta)(\alpha+\sigma(1-\alpha))} .
$$

From equation (34) it is then straight-forward to obtain the following benefit rate and contribution rate, respectively:

$$
\begin{aligned}
\gamma_{E, t} & =\frac{\sigma(1-\alpha) \beta(1-\sigma)}{n_{t}(1+\beta)(\alpha+\sigma(1-\alpha))} \\
\tau_{E} & =\frac{\sigma(1-\alpha) \beta(1-\sigma)}{(1+\beta)(\alpha+\sigma(1-\alpha))}
\end{aligned}
$$

In the closed economy the market outcome resembles an education system according to a pure FC scheme, i.e. $\phi_{E}=0$.

\subsubsection{Small open economy}

In this case factor prices are constant, which via workers' optimization implies $R=R_{t+1}^{H}$, and together with equation (30) we get:

$$
\gamma_{E, t}=\frac{\sigma h_{t+1}}{R h_{t}}
$$


This condition is satisfied with a constant benefit rate. ${ }^{20}$ If we further assume that the steady state interest rate for a closed economy is the same as the world interest rate, then it is possible to obtain the following rates for the education system:

$$
\begin{aligned}
\gamma_{E} & =\frac{\sigma(1-\alpha) \beta(1-\sigma)}{(1+\beta)(\alpha+\sigma(1-\alpha)) n} \\
\tau_{E, t} & =\frac{\sigma(1-\alpha) \beta(1-\sigma) n_{t}}{(1+\beta)(\alpha+\sigma(1-\alpha)) n} .
\end{aligned}
$$

Thus, in a small open economy, the market outcome corresponds to an education system with pure FB and a pension system with pure FC .

\subsection{Market outcome and the exogenous systems}

It is possible for the exogenous education and pension systems to mimic the market outcome. ${ }^{21}$ What is needed, for the closed economy and the small open economy, is to define the benefit rates as in the market outcome, as presented in table 4.

Table 4: Benefit rates in the market outcome.

\begin{tabular}{ccc}
\hline \hline & Open ec. & Closed ec. \\
& $\phi_{K}=1$ & $\phi_{K}=0$ \\
\hline$\gamma_{P, t}$ & $\sigma n_{t-1}$ & $\sigma n_{t-1}$ \\
$\phi_{P}$ & $0(\mathrm{FC})$ & $0(\mathrm{FC})$ \\
& & \\
$\gamma_{E, t}$ & $\frac{\sigma \beta(1-\alpha)(1-\sigma)}{(1+\beta)(\alpha+\sigma(1-\alpha))}$ & $\frac{\sigma \beta(1-\alpha)(1-\sigma)}{n_{t}(1+\beta)(\alpha+\sigma(1-\alpha))}$ \\
$\phi_{E}$ & $1(\mathrm{FB})$ & $0(\mathrm{FC})$ \\
\hline \hline
\end{tabular}

With these benefit rates the systems will mimic the market outcome. Without having any explicit link between the contributions to the education system and the benefits in the pension system, the systems will still behave as if pension benefits were a return on human capital investments.

\footnotetext{
${ }^{20}$ Note that FB education design in the small open economy implies $h_{t}=h \forall t$.

${ }^{21}$ Boldrin and Montes (2005) note that it is difficult to mimic the market outcome without lump-sum taxation, since income taxation leads to distortions. In this model this is not a problem due to inelastic labor supply. Moreover, it should be possible to avoid such distortions if applying participation constraints in the pension system, similar to the Swedish unfunded pension system. The Swedish pension system is a pure FC pension system where the pension benefits are related to life-time income.
} 
In the small open economy the exogenous $\phi_{E}$ and $\phi_{P}$ pair that maximized expected welfare, is the same combination as in the market outcome. For the closed economy this is not the case. The $\phi_{E}$ and $\phi_{P}$ pair presented in table 1 yields a higher expected welfare than the market outcome. This is no surprise since the market outcome did not allow for the generations to specify contracts ex ante, before the uncertainty was realized, for all future realizations.

Maximizing the welfare function ex ante incorporates the diversification effect that the FB pension schemes offers. For $n_{t}>n$ the change in interest rate will be such that $R_{t+1}>R$ (unless the economy is a small open one). From table 3 it is clear that if the pension scheme is a pure FB scheme then $R_{t+1}^{H}<R$, irrespective of education design. This will thus imply a diversification effect, that all generations benefit from, given that they are risk-averse. If the pension system is a pure $\mathrm{FC}$ scheme and the education system a pure FC scheme then $R_{t+1}^{H}$ moves together with $R_{t+1}$, and the investment in human capital will thus not offer any diversification effect.

\section{Discussion}

The underlying question in this paper was if a unfunded pension system with a fixed contribution rate is desirable when considering changes in dependency ratios. When considering fertility fluctuations from an ex ante perspective then the optimal pension design was shown to depend crucially on the degree of openness. For a closed economy a fixed benefit rate is preferred, which confirms findings in other studies. It was further shown that this result holds even with considerable degree of openness, and irrespective of how the education system might be financed.

For a fully open economy the pure FC pension scheme is desirable if it is possible to design the education system to be a pure FB scheme. This specific design combination for the education system and the pension system implies that individuals in the small open economy are unaffected by fertility fluctuations, even with large intergenerational transfer systems in place.

The paper also investigated what kind of allocations that would arise in the market outcome when children and adults can enter into contractual agreements. The finding is that the resulting transactions in the closed economy resemble a pure FC pension scheme and a pure FC education scheme. For the small open economy the arising allocations are the same as for the pure FC pension scheme combined with a pure FB education scheme.

For the closed economy the market outcome does not yield the highest expected welfare. This depends on the fact that the market outcome leads 
to the same rate of return on both human and physical capital. From an ex ante perspective one would want these two form of capital to be negatively correlated. This is accomplished by a pure FB pension scheme.

The opposing results about the pension scheme when viewed ex ante (maximizing expected welfare) and when viewed ex post (market outcome when the uncertainty has realized) leads to the question of sustainability. Is it possible to impose a pension system that deviates from the market outcome? This is left to future research but it is interesting that countries who have re-designed their pension system have moved from a fixed replacement rate to a fixed contribution rate (e.g. Sweden, Italy, Germany). This is noteworthy since the fixed replacement rate can never replicate the market outcome. The move towards FC could be motivated as an attempt to replicate the market outcome, in which case it would require that the corresponding education design is in place. This would, however, imply that unlucky generations, i.e. the large ones, would bear a huge cost in economies that are not small and open.

Linking the education design with the pension design is crucial to minimize the effects of fertility fluctuations. This does not imply that the two should have a unified budget constraint, such that the pension benefits will depend on education contributions. What is needed is to specify how the systems will react to changes in dependency ratios. For this reason the long-term intergenerational contract in the education system should be made explicit. If we want to give equal opportunities of education, across generations, then introducing an explicit educational long-term contract according to the FB scheme might be warranted. If this would be the case then the FC pension scheme is desirable for a small open economy.

There are many important aspects that have been left out from the analysis, e.g. uncertainties about the mortality rate, productivity, and the like. The stylized model did not capture the effects that a varying tax rate could have on the labor supply. Has this made the analysis biased towards the FB scheme? This depends on whether the income or the substitution effect dominates. Another possibility is to make fertility endogenous. This would probably lead to inclusion of altruism into the model. Including altruism would probably not dismantle the qualitative prescriptions. This since the results regarding preferred designs mainly rest on how different designs minimize the effects of fertility fluctuations. Moreover, assuming parental altruism towards children would probably strengthen the results since a large cohort is worse off than the parent generation even without altruism. The fact that a large cohort is worse off and that the preferred pension design tries to compensate for this, implies that the results probably would be strengthen if allowing for different utilities during childhood. 


\section{References}

Auerbach, A. J. and Kotlikoff, L. J.: 1987, Dynamic Fiscal Policy, Cambridge University Press.

Augustinovics, M.: 1999, Pension systems and reforms in the transition economies, The Economic Survey of Europe, number 3, United Nations Economic Commission for Europe, chapter 4, pp. 89-114.

Ball, L. and Mankiw, N. G.: 2001, Intergenerational risk sharing in the spirit of arrow, debreu, and rawls, with applications to social security design, NBER Working Paper (No. 8270).

Becker, G. S. and Murphy, K. M.: 1988, The family and the state, Journal of Law and Economics 31(1), 1-18.

Blanchet, D. and Kessler, D.: 1991, Optimal pension funding with demographic instability and endogenous returns on investment, Journal of Population Economics 4(2), 137-154.

Blomquist, S. and Wijkander, H.: 1994, Fertility waves, aggregate savings and the rate of interest, Journal of Population Economics 7, 27-48.

Boadway, R., Marchand, M. and Pestieau, P.: 1991, Pay-as-you-go social security in a changing environment, Journal of Population Economics 4(4), 257-280.

Bohn, H.: 2001, Social security and demographic uncertainty: The risk sharing properties of alternative policies, in J. Campbell and M. Feldstein (eds), Risk Aspects of Investment Based Social Security Reform, University of Chicago Press, pp. 203-241.

Boldrin, M. and Montes, A.: 2005, The intergenerational state education and pensions, Review of Economic Studies 72, 651-664.

Card, D. and Krueger, A. B.: 1992, Does school quality matter? returns to education and the characteristics of public schools in the united states, The Journal of Political Economy 100(1), 1-40.

Cutler, D. M., Poterba, J. M., Sheiner, L. M. and Summers, L. H.: 1990, An aging society: Opportunity or challenge?, Brookings Papers on Economic Activity 1990(1), 1-73. 
Hassler, J. and Lindbeck, A.: 1997, Intergenerational risk sharing, stability and optimality of alternative pension systems, Seminar Paper 631, Institute for International Economic Studies, Stockholm University.

Kotlikoff, L. J. and Summers, L. H.: 1981, The role of intergenerational transfers in aggregate capital accumulation, The Journal of Political Economy 89(4), 706-732.

Lindbeck, A.: 2000, Pensions and contemporary socioeconomic change, Seminar Paper 685, Institute for International Economic Studies, Stockholm University.

Obstfeld, M. and Rogoff, K.: 2000, The six major puzzles in international macroeconomics: Is there a common cause?, Working Paper 7ryry, National Bureau of Economic Research.

Rangazas, P.: 2002, The quantity and quality of schooling and US labor productivity growth (1870-2000), Review Of Economic Dynamics 5(4), 932964.

Rangel, A.: 2003, Forward and backward intergenerational goods: Why is social security good for the environment?, American Economic Review 93(3), 813-34.

Schmitt-Grohé, S. and Uribe, M.: 2003, Closing small open economy models, Journal of International Economics 61, 163-185.

Smith, A.: 1982, Intergenerational transfers as social insurance, Journal of Public Economics 19(1), 97-106.

Thøgersen, Ø.: 1998, A note on intergenerational risk sharing and the design of pay-as-you-go pension programs, Journal of Population Economics 11(3), 373-378.

Žamac, J.: 2005, Winners and losers from a demographic shock under different intergenerational transfer schemes, Working Paper 2005:13, Uppsala University, Department of Economics.

Wagener, A.: 2003, Pensions as a portfolio problem: fixed contribution rates vs. fixed replacement rates reconsidered, Journal of Population Economics 16(1), 111-134.

Wagener, A.: 2004, On intergenerational risk sharing within social security schemes, European Journal of Political Economy 20(1), 181-206. 


\title{
CESifo Working Paper Series
}

\author{
(for full list see www.cesifo-group.de)
}

1509 Jean Hindriks and Ben Lockwood, Decentralization and Electoral Accountability: Incentives, Separation, and Voter Welfare, July 2005

1510 Michelle R. Garfinkel, Stergios Skaperdas and Constantinos Syropoulos, Globalization and Domestic Conflict, July 2005

1511 Jesús Crespo-Cuaresma, Balázs Égert and Ronald MacDonald, Non-Linear Exchange Rate Dynamics in Target Zones: A Bumpy Road towards a Honeymoon - Some Evidence from the ERM, ERM2 and Selected New EU Member States, July 2005

1512 David S. Evans and Michael Salinger, Curing Sinus Headaches and Tying Law: An Empirical Analysis of Bundling Decongestants and Pain Relievers, August 2005

1513 Christian Keuschnigg and Martin D. Dietz, A Growth Oriented Dual Income Tax, July 2005

1514 Fahad Khalil, David Martimort and Bruno Parigi, Monitoring a Common Agent: Implications for Financial Contracting, August 2005

1515 Volker Grossmann and Panu Poutvaara, Pareto-Improving Bequest Taxation, August 2005

1516 Lars P. Feld and Emmanuelle Reulier, Strategic Tax Competition in Switzerland: Evidence from a Panel of the Swiss Cantons, August 2005

1517 Kira Boerner and Silke Uebelmesser, Migration and the Welfare State: The Economic Power of the Non-Voter?, August 2005

1518 Gabriela Schütz, Heinrich W. Ursprung and Ludger Wößmann, Education Policy and Equality of Opportunity, August 2005

1519 David S. Evans and Michael A. Salinger, Curing Sinus Headaches and Tying Law: An Empirical Analysis of Bundling Decongestants and Pain Relievers, August 2005

1520 Michel Beine, Paul De Grauwe and Marianna Grimaldi, The Impact of FX Central Bank Intervention in a Noise Trading Framework, August 2005

1521 Volker Meier and Matthias Wrede, Pension, Fertility, and Education, August 2005

1522 Saku Aura and Thomas Davidoff, Optimal Commodity Taxation when Land and Structures must be Taxed at the Same Rate, August 2005

1523 Andreas Haufler and Søren Bo Nielsen, Merger Policy to Promote 'Global Players’? A Simple Model, August 2005 
1524 Frederick van der Ploeg, The Making of Cultural Policy: A European Perspective, August 2005

1525 Alexander Kemnitz, Can Immigrant Employment Alleviate the Demographic Burden? The Role of Union Centralization, August 2005

1526 Baoline Chen and Peter A. Zadrozny, Estimated U.S. Manufacturing Production Capital and Technology Based on an Estimated Dynamic Economic Model, August 2005

1527 Marcel Gérard, Multijurisdictional Firms and Governments' Strategies under Alternative Tax Designs, August 2005

1528 Joerg Breitscheidel and Hans Gersbach, Self-Financing Environmental Mechanisms, August 2005

1529 Giorgio Fazio, Ronald MacDonald and Jacques Mélitz, Trade Costs, Trade Balances and Current Accounts: An Application of Gravity to Multilateral Trade, August 2005

1530 Thomas Christiaans, Thomas Eichner and Ruediger Pethig, A Micro-Level 'Consumer Approach’ to Species Population Dynamics, August 2005

1531 Samuel Hanson, M. Hashem Pesaran and Til Schuermann, Firm Heterogeneity and Credit Risk Diversification, August 2005

1532 Mark Mink and Jakob de Haan, Has the Stability and Growth Pact Impeded Political Budget Cycles in the European Union?, September 2005

1533 Roberta Colavecchio, Declan Curran and Michael Funke, Drifting Together or Falling Apart? The Empirics of Regional Economic Growth in Post-Unification Germany, September 2005

1534 Kai A. Konrad and Stergios Skaperdas, Succession Rules and Leadership Rents, September 2005

1535 Robert Dur and Amihai Glazer, The Desire for Impact, September 2005

1536 Wolfgang Buchholz and Wolfgang Peters, Justifying the Lindahl Solution as an Outcome of Fair Cooperation, September 2005

1537 Pieter A. Gautier, Coen N. Teulings and Aico van Vuuren, On-the-Job Search and Sorting, September 2005

1538 Leif Danziger, Output Effects of Inflation with Fixed Price- and Quantity-Adjustment Costs, September 2005

1539 Gerhard Glomm, Juergen Jung, Changmin Lee and Chung Tran, Public Pensions and Capital Accumulation: The Case of Brazil, September 2005

1540 Yvonne Adema, Lex Meijdam and Harrie A. A. Verbon, The International Spillover Effects of Pension Reform, September 2005 
1541 Richard Disney, Household Saving Rates and the Design of Social Security Programmes: Evidence from a Country Panel, September 2005

1542 David Dorn and Alfonso Sousa-Poza, Early Retirement: Free Choice or Forced Decision?, September 2005

1543 Clara Graziano and Annalisa Luporini, Ownership Concentration, Monitoring and Optimal Board Structure, September 2005

1544 Panu Poutvaara, Social Security Incentives, Human Capital Investment and Mobility of Labor, September 2005

1545 Kjell Erik Lommerud, Frode Meland and Odd Rune Straume, Can Deunionization Lead to International Outsourcing?, September 2005

1546 Robert Inklaar, Richard Jong-A-Pin and Jakob de Haan, Trade and Business Cycle Synchronization in OECD Countries: A Re-examination, September 2005

1547 Randall K. Filer and Marjorie Honig, Endogenous Pensions and Retirement Behavior, September 2005

1548 M. Hashem Pesaran, Til Schuermann and Bjoern-Jakob Treutler, Global Business Cycles and Credit Risk, September 2005

1549 Ruediger Pethig, Nonlinear Production, Abatement, Pollution and Materials Balance Reconsidered, September 2005

1550 Antonis Adam and Thomas Moutos, Turkish Delight for Some, Cold Turkey for Others?: The Effects of the EU-Turkey Customs Union, September 2005

1551 Peter Birch Sørensen, Dual Income Taxation: Why and how?, September 2005

1552 Kurt R. Brekke, Robert Nuscheler and Odd Rune Straume, Gatekeeping in Health Care, September 2005

1553 Maarten Bosker, Steven Brakman, Harry Garretsen and Marc Schramm, Looking for Multiple Equilibria when Geography Matters: German City Growth and the WWII Shock, September 2005

1554 Paul W. J. de Bijl, Structural Separation and Access in Telecommunications Markets, September 2005

1555 Ueli Grob and Stefan C. Wolter, Demographic Change and Public Education Spending: A Conflict between Young and Old?, October 2005

1556 Alberto Alesina and Guido Tabellini, Why is Fiscal Policy often Procyclical?, October 2005

1557 Piotr Wdowinski, Financial Markets and Economic Growth in Poland: Simulations with an Econometric Model, October 2005 
1558 Peter Egger, Mario Larch, Michael Pfaffermayr and Janette Walde, Small Sample Properties of Maximum Likelihood Versus Generalized Method of Moments Based Tests for Spatially Autocorrelated Errors, October 2005

1559 Marie-Laure Breuillé and Robert J. Gary-Bobo, Sharing Budgetary Austerity under Free Mobility and Asymmetric Information: An Optimal Regulation Approach to Fiscal Federalism, October 2005

1560 Robert Dur and Amihai Glazer, Subsidizing Enjoyable Education, October 2005

1561 Carlo Altavilla and Paul De Grauwe, Non-Linearities in the Relation between the Exchange Rate and its Fundamentals, October 2005

1562 Josef Falkinger and Volker Grossmann, Distribution of Natural Resources, Entrepreneurship, and Economic Development: Growth Dynamics with Two Elites, October 2005

$1563 \mathrm{Yu}-\mathrm{Fu}$ Chen and Michael Funke, Product Market Competition, Investment and Employment-Abundant versus Job-Poor Growth: A Real Options Perspective, October 2005

1564 Kai A. Konrad and Dan Kovenock, Equilibrium and Efficiency in the Tug-of-War, October 2005

1565 Joerg Breitung and M. Hashem Pesaran, Unit Roots and Cointegration in Panels, October 2005

1566 Steven Brakman, Harry Garretsen and Marc Schramm, Putting New Economic Geography to the Test: Free-ness of Trade and Agglomeration in the EU Regions, October 2005

1567 Robert Haveman, Karen Holden, Barbara Wolfe and Andrei Romanov, Assessing the Maintenance of Savings Sufficiency Over the First Decade of Retirement, October 2005

1568 Hans Fehr and Christian Habermann, Risk Sharing and Efficiency Implications of Progressive Pension Arrangements, October 2005

1569 Jovan Žamac, Pension Design when Fertility Fluctuates: The Role of Capital Mobility and Education Financing, October 2005 